\title{
Detection, assessment, and updating the maps of encroached forest areas: a case study from Bara district, Nepal
}

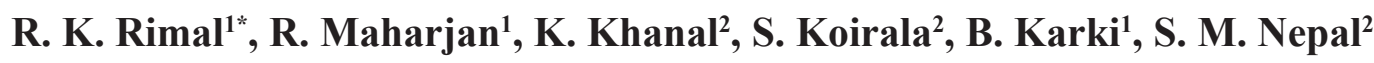 \\ and H. L. Shrestha ${ }^{3}$
}

Forest encroachment is an illegal expansion of cultivable land and settlements within the jurisdiction of forests. It has been the key threat to forest management for the last several years in Nepal. The Department of Forests (DoF) is the responsible authority for detection and assessment of forest encroachment throughout the nation and updating the forest maps accordingly. Detection and preparing the updated maps of encroached forest areas is necessary for sustainable management of forests. Traditionally, the extent of forest encroachment is assessed through estimation by the front-line forestry staff. The new approach combines the aerial photographs, the cadastral maps prepared by the Department of Survey and the Google Earth Imagery to spatially locate the encroachment. This method will work as a desktop tool for the forest manager such that appropriate strategic actions can be taken immediately. Additionally, it will bring a transparency on the forest governance to identify the location of areas of interest like point location for forest-based industries or proposed sites for development of infrastructures on the ground. The local communities may use the tool to identify the actual location of the forest boundaries, and exert social pressure to relinquish the encroached forests, if any.

The result showed that 8,540 ha of the forest area in Bara district was found to be encroached during the period of last 50 years, between 1964 and 2014, of which $71 \%(6,038 \mathrm{ha})$ happened to be encroached in the first three decades, indicating the retarding trend of encroachment in the later years. The methodology used to assess the encroachment of forest in Bara district can be easily scaled up to other districts too, and will eventually help to assess the country's overall forest encroachment. Since the boundary delineation will be done on the basis of the cadastral maps, the output will be used as a robust evidence to defend the forest-related cased in the court during the legal arbitrations

Key words: Cadastral map, change detection, encroachment, forest cover loss

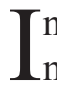
Nepal, forests are managed through different management regimes, under the jurisdiction of the Government of Nepal. The protected area network (national parks, wildlife reserves, conservation areas, buffer zones and protection forests) comprises $23.39 \%$ of the total land area of the country (DNPWC, 2016). This is followed by the community-managed forest which covers 1.79 million hectares, about $27 \%$ of the total forest area in Nepal (DoF, 2016). Other forest regimes fall under the government, private, collaborative and leasehold forest management systems.
The forests in Nepal are facing degradation and depletion due to several proximate causes including uncontrolled forest fire, overgrazing, unsustainable extraction of forest products for local consumption and development infrastructures such as transmission lines, roads, canals and hydro-power due to population growth (Geist and Lambin, 2001; DFRS, 1999). Besides, other socio-economic trends such as migration of people from the mountains and hills to the Terai and other accessible areas have also impacted upon the forests. A report indicates that migration

\footnotetext{
${ }^{1}$ Department of Forests, Babarmahal, Kathmandu. *E-mail: rajkumarrimal@gmail.com

${ }^{2}$ World Wildlife Fund Nepal,

${ }^{3}$ EbA South Project, Ministry of Population, Kathmandu, Nepal
} 
within the nation is also responsible for forest cover loss mostly in the Terai region (WWF, 2014).

In the Nepalese context, forest encroachment is the illegal conversion of forested land to other land uses, such as agriculture and settlement. It is one of the major drivers of deforestation and forest degradation in Nepal (Acharya et al., 2011) which is more prominent in the Terai and Siwalik regions. Some encroachments have been done illegally in the Terai forests, especially along the East-West highway, for the expansion of local markets.

Satellite Remote Sensing (RS) coupled with Geographical Information System (GIS) is one of the viable techniques to monitor the changing pattern of forests. Satellite data from several moments in time allows the creation of land cover maps over the large spatial extents and more frequent time intervals than with expensive and detailed field studies (Nagendra, 2001). Human encroachment on forest land gives rise to the change in another type of land use. Further, land use change by human activities through encroachment has become a proximate factor that catalyzes the deforestation and forest degradation (Tole, 1998). It was estimated that 80,635 ha of forest area was encroached (published in Rising Nepal dated September 28, 2007) and this trend of encroachment is seemingly increasing. Hence, detection of forest encroachment provides useful information for planning and sustainable management of forests.

The problem of forest encroachment has become a sensitive issue over the years. The government of Nepal has formulated the policy of Forest Encroachment Control and Management Strategy, 2012 ' to address the problem, but the scientific and reliable data on forest encroachment are unavailable. The Department of Forests (DoF) felt the direct need of GIS/RS based updated forest maps to address the problem. Various time series forest cover data such as the 1964 Aerial Photographs, the 1960s National Forest Inventory (NFI) data, the 1990s NFI data and the 20102014 NFI data produced by the Department of Forest Research and Survey (DFRS) and the 1994 and the 1996 Topographic Maps of Nepal and the digital cadastral information produced by the Department of Survey(DoS) are available. These data can be analyzed for temporal monitoring of the forest cover. The change in forest cover by several actors and drivers can be detected, assessed and updated both at national- and district-levels using these dataset.

This pilot study aims to detect forest encroachment and update forest maps in Bara district using cadastral maps, google image and historical images, and provide a methodology for the encroachment detection that can be used to update forest maps for all the districts of Nepal.

\section{Materials and methods}

\section{Study area}

The study was carried out in Bara district which is located in the south-central lowland Terai region of Nepal. The district is bounded by Rautahat district on the east, Parsa district on the west, Makawanpur district on the north and India on the south (Fig. 1). It is located between $26^{\circ} 61^{\prime}-27^{\circ}$ $02^{\prime} \mathrm{N}$ latitudes and $84^{\circ} 51^{\prime}-85^{\circ} 16^{\prime}$ 'E longitudes.

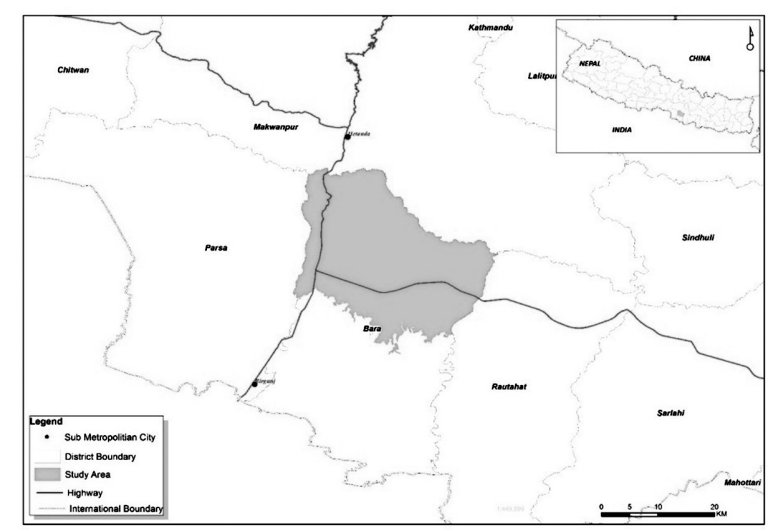

Fig. 1: Map showing the location of the study Area

The northern part of Bara district covering 60,914 ha was set aside as the study area which covered 59,348 ha forest land and 1,566 ha non-forest land using the 1964 Aerial Photographs. The area on the southern part has been digitized as settlement area in the Cadastral Map and was, therefore, not included in the study. The conversion of forest and Non-forest land within the area of 60,914 ha was the major focus where the change detection was analyzed.

\section{Methodology}

The available data from the Google Earth, Topographical Sheets, Cadastral Map, historical data, 1964 Aerial Photographs and various time series satellite images were gathered and scanned. 
These data were geo-referenced by using ArcGIS 10.3 to avoid errors by providing adequate ground control points. This was followed by geo-spatial analysis where the geo-referenced cadastral maps were digitized. These data were overlaid on the Google Earth images for detecting the encroached forest areas. On the other hand, various time series data were analyzed to find out the change in forest area during the different time periods. Different geo-processing tools such as clip, mosaic, dissolve, union, merge and spatial join were used to generate precise results. This was followed by digitization of the various time series data to generate polygon of forest and Non-forest areas, and the encroached forest areas were identified with the help of the ArcGIS Software. The attribute data were obtained from the digitized maps, and were analyzed (using the MS Excel Sheet). The detected areas were verified in the field through field observation and consultation with the District Forest Officer and other stakeholders. Fig. 2 highlights the methodology applied in this study.

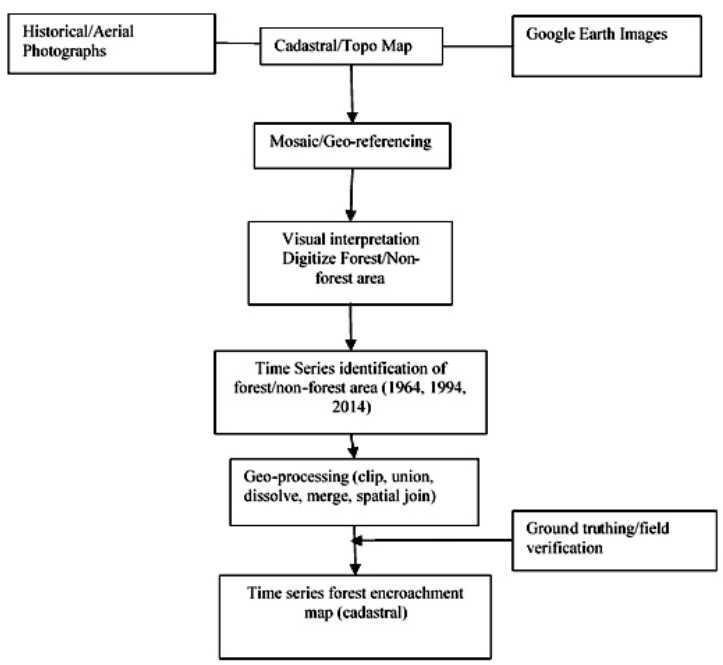

Fig. 2: Methodological framework

\section{Data source}

Table 1 shows the different data and maps used for change detection analysis, and their sources.

\section{Results and discussion}

\section{Land use}

Bara district went through severe changes in its land use during the last 50 years (1964-2014). This change was mainly due to industrialization and migration of people from the mountains and Hills to the Terai. The analysis of data shows that the Non-forestland increased from 1,566 ha to 10,106 ha during the period of 50 years, from 1964 to 2014 (Fig. 3). The Non-forestland increased to almost 5 folds during the last 30 years, from 1964 to 1994, and 6 folds in 2014 than in the base year (1964). The major reason behind this was the rapid establishment of big industries and expansion of settlement areas. Bara district lies close to the Indian border, and so it is easier to import raw materials from India, leading to the establishment of major industries, which has subsequently led to the reduction in the forest area in the district. The forest area was found to have decreased from 59,348 ha to 50,808 ha during the period, from 1964 to 2014.

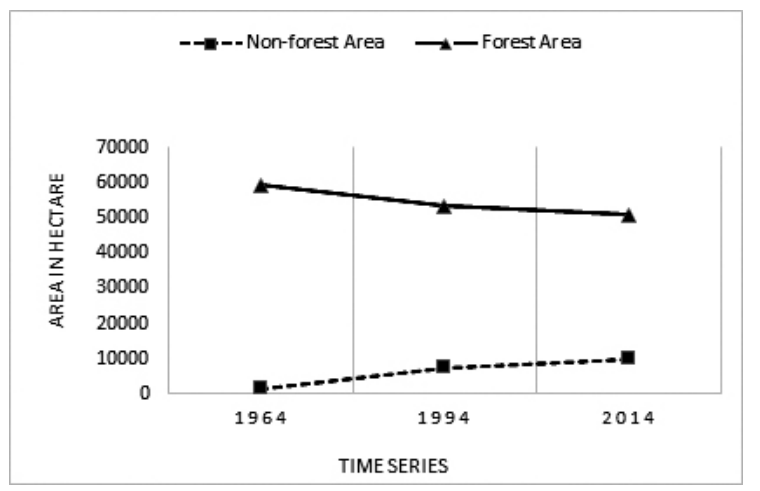

Fig. 3: Land use change in Bara district during 1964-2014

Table 1: Data acquisition

\begin{tabular}{|c|c|c|c|}
\hline Data & Year & Characteristics & Source \\
\hline $\begin{array}{l}1964 \text { Aerial } \\
\text { Photographs }\end{array}$ & 1964 & $\begin{array}{l}\text { Black and white, } 300 \text { DPI, } \\
10,000-12,000 \text { Scale }\end{array}$ & $\begin{array}{l}\text { Department of Forest Research and } \\
\text { Survey (DFRS) }\end{array}$ \\
\hline Topographic maps & 1994 & $1: 25000$ scale & Department of Survey (DoS) \\
\hline $\begin{array}{l}\text { High-resolution } \\
\text { Google Image }\end{array}$ & 2014 & High-resolution imagery & Google Earth \\
\hline Cadastral Map & NA & Parcel Map & $\begin{array}{l}\text { National Land Use Mapping Project } \\
\text { (LRMP) and Department of Land } \\
\text { Information and Archive (DOLIA) }\end{array}$ \\
\hline
\end{tabular}


Forest encroachment during the period of 1964-1994

The DoS had conducted a survey of Bara district in 1964, and developed a cadastral map of the district. During the survey, the settlement areas including the cultivated land were demarcated, and the rest of the areas were considered as forest. All the lands based on the ownership (kitta) of the people were digitized. In 1964, the total forest land within the study area was 59,348 ha while the cultivated land was only 1,566 ha. This provided the baseline for the forest cover change analysis. During the period of 1964 to 1994, Bara district observed the expansion of industrial area and human migration from the mountains and the Chure hills to the lower flat land which was the major cause for the encroachment of forest areas in the Terai. Besides this, the forest loss was also triggered due to the resettlement program at Nijgadh in Bara district. The resettlement was done from Shaktikhola and Campadada of Makawanpur district to Nijgadh in Bara district. Besides, the promotion of medicinal plants in almost 300 ha in the the Kakadi Village Development Committee (VDC) also reduced the forest area of the district to some extent. These government programs along with the establishment of industrial areas and illegal expansion of cultivated lands as well as settlements were the main causes for the decrease of 6,038 ha of the forest area in the district. The study showed that Nijgadh, Ratanpuri and Dumarwana VDCs of Bara district had suffered a huge loss of forest during the last fifty years, from 1964 to 2014 (Fig. 4).

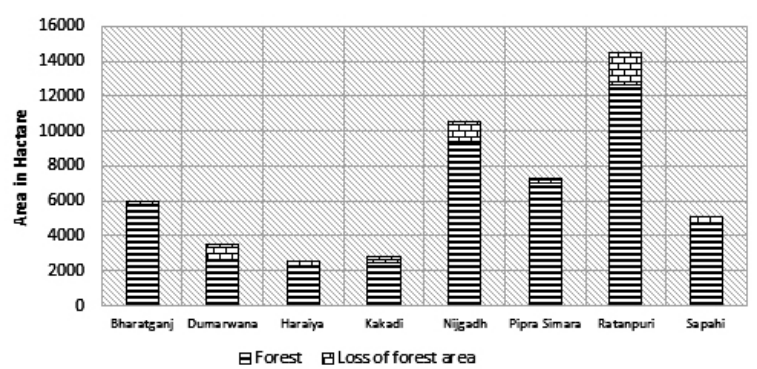

Fig. 4: VDC-wise forest cover loss in Bara district from 1964 to 1994

Forest encroachment during the period of 1994 to 2014

During the later 20-year period, from 1994 to 2014 , the conversion in the land use was relatively low as compared to the one in the earlier 30 years (1964-1994) of the study period (1964-2014). There was a loss of 2,502 ha of forest, and the major changes were observed in the Ratanpuri, Kakadi and Bharatganj VDCs, comprising almost $58 \%(1,446$ ha) of the total forest loss (Fig. 5).

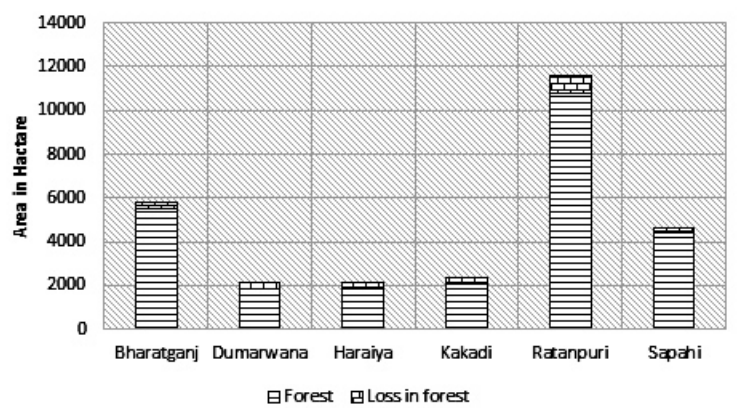

Fig. 5: VDC-wise forest cover loss in Bara district from 1994 to 2014

Forest encroachment and forest change
analysis

As has been already mentioned beforehand, significant forest areas in Bara district were found to have been converted into other land uses during the period of 1964 to 2014 (Fig. 6a, 6b, $6 c)$. Considering all the causes of forest loss as encroachment, highest encroachment happened between the period of 1964 and 1994. The area of encroached land accounted to 6,038 ha which was about $60 \%$ of the total encroachment (Fig. 7).

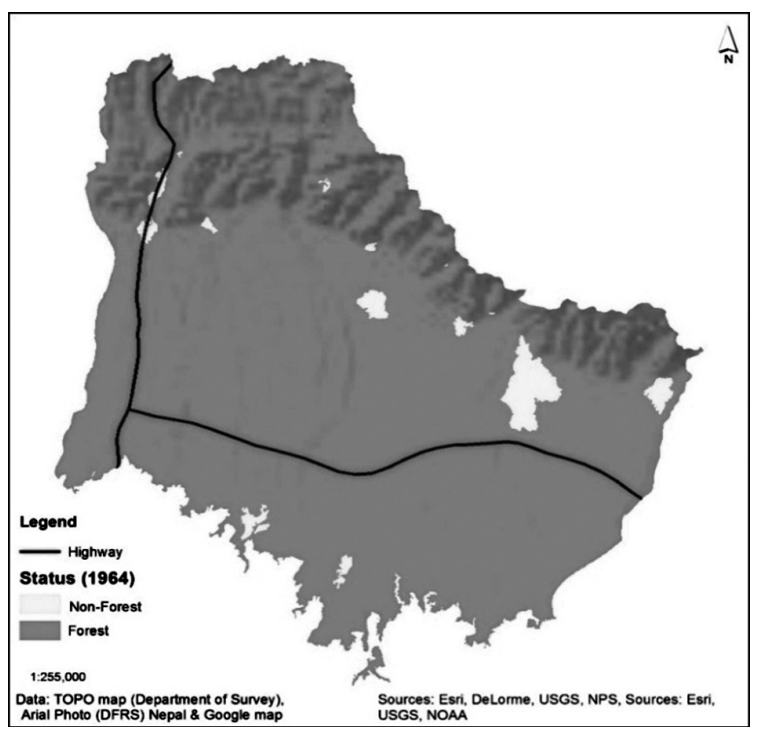

Fig. 6a: Forest encroachment in Bara district in 1964 


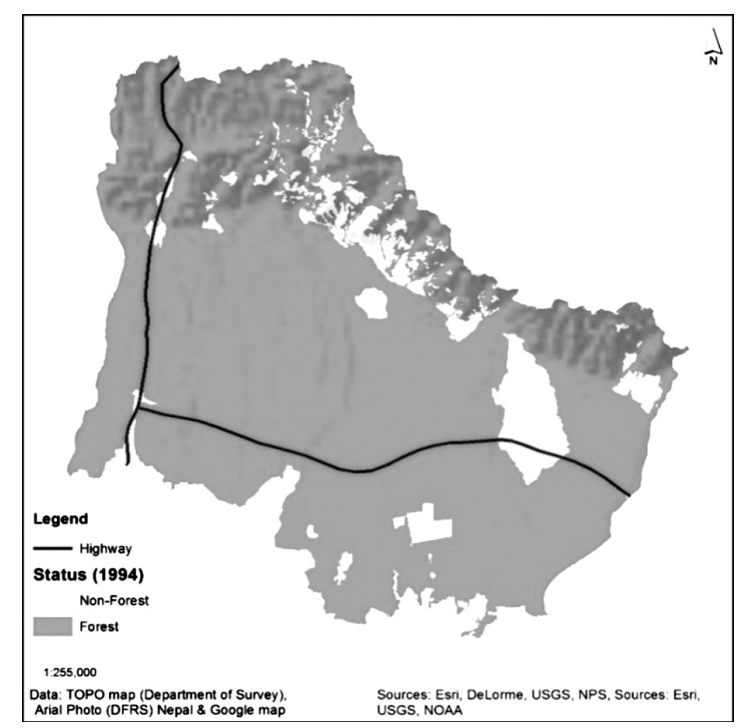

Fig. 6b: Forest encroachment in Bara district in 1994

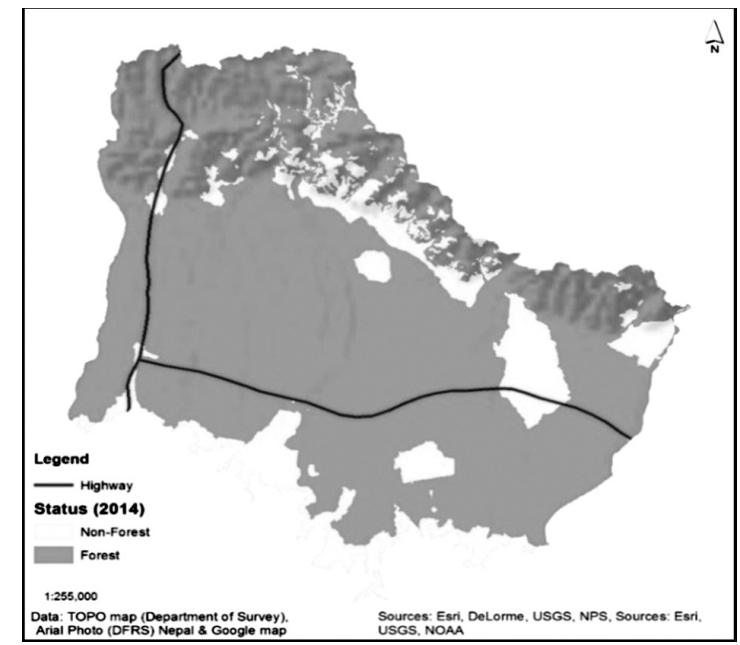

Fig. 6c: Forest encroachment in Bara district in 2014

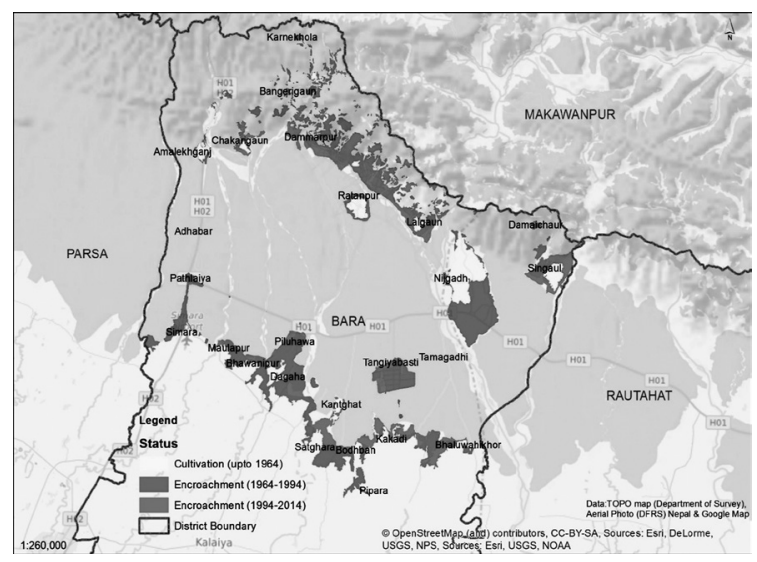

Fig. 7: Forest encroachment in Bara district during the periods of 1964-1994 and 19942014

Encroachments in the different VDCs of Bara district during the last fifty-year period (1964-
2014) are indicated in the Table 2.

Table 2: VDCs-wise assessment of forest encroachment during 1964-1994 and 1994-2014

\begin{tabular}{|c|c|}
\hline VDC-wise Forest to Non-forest & Area (Ha) \\
\hline Amlekhganj & 324 \\
\hline Forest to Non-forest (1964-1994) & 199 \\
\hline Forest to Non-forest (1994-2014) & 124 \\
\hline Bharatganj Sinaul & 522 \\
\hline Forest to Non-forest (1964-1994) & 227 \\
\hline Forest to Non-forest (1994-2014) & 295 \\
\hline Bhodaha & 15 \\
\hline Forest to Non-forest (1964-1994) & 15 \\
\hline Dumarwana & 1,069 \\
\hline Forest to Non-forest (1964-1994) & 822 \\
\hline Forest to Non-forest (1994-2014) & 248 \\
\hline Haraiya & 564 \\
\hline Forest to Non-forest (1964-1994) & 325 \\
\hline Forest to Non-forest (1994-2014) & 239 \\
\hline Jitpur & $\mathbf{0}$ \\
\hline Forest to Non-forest (1964-1994) & 0 \\
\hline Kakadi & 727 \\
\hline Forest to Non-forest (1964-1994) & 392 \\
\hline Forest to Non-forest (1994-2014) & 334 \\
\hline Karaiya & 109 \\
\hline Forest to Non-forest (1964-1994) & 73 \\
\hline Forest to Non-forest (1994-2014) & 35 \\
\hline Kolbi & 4 \\
\hline Forest to Non-forest (1964-1994) & 4 \\
\hline Manaharwa & 331 \\
\hline Forest to Non-forest (1964-1994) & 192 \\
\hline Forest to Non-forest (1994-2014) & 139 \\
\hline Nijgadh & 1,103 \\
\hline Forest to Non-forest (1964-1994) & 1084 \\
\hline Forest to Non-forest (1994-2014) & 19 \\
\hline Parsauna & 53 \\
\hline Forest to Non-forest (1964-1994) & 48 \\
\hline Forest to Non-forest (1994-2014) & 6 \\
\hline PipraSimara & 360 \\
\hline Forest to Non-forest (1964-1994) & 332 \\
\hline Forest to Non-forest (1994-2014) & 29 \\
\hline Ratanpuri & 2,673 \\
\hline Forest to Non-forest (1964-1994) & 1857 \\
\hline Forest to Non-forest (1994-2014) & 815 \\
\hline Sapahi & 556 \\
\hline Forest to Non-forest (1964-1994) & 337 \\
\hline Forest to Non-forest (1994-2014) & 219 \\
\hline Sihorwa & 88 \\
\hline Forest to Non-forest (1964-1994) & 88 \\
\hline Tetariya & 42 \\
\hline Forest to Non-forest (1964-1994) & 42 \\
\hline Umajan & 2 \\
\hline Forest to Non-forest (1964-1994) & 2 \\
\hline
\end{tabular}




\begin{tabular}{lc}
\hline Grand Total & $\mathbf{8 , 5 4 0}$ \\
\hline
\end{tabular}

Note: Non-forest denotes the forest loss caused by humans, such as cultivation, settlement and other developmental activities, but the forest loss due to natural calamities has not been considered.

\section{Categorization of forest conversion}

Over the years, forests were either encroached or cleared off for different purposes such as the expansion of settlement for cultivation, establishing various infrastructures including government/public buildings, playgrounds, temples, community buildings and so on. These forest encroachments can be re-classified as the forest encroachment/conversion for- cultivation, settlement, construction of government infrastructures and construction of social infrastructures. The conversion of forest for the purpose of cultivation was found to be the highest accounting for 7,510 ha followed by settlement with 911 ha. Similarly, the conversion of forest for the purpose of the construction of government structures such as the government offices, schools, roads, health posts and so on, and accounted for 26 ha followed by the construction of social structures such as playgrounds, temples and community buildings, accounting for 24 ha. Besides these categories, about 1,636 ha of forest area were found to be at the stage of being cleared off, and so were categorized as potential conversion.

Table 3: Categorization of forest conversion

\begin{tabular}{llr}
\hline S. N. & Forest conversion type & Area (ha) \\
\hline 1. & Cultivation & 7,510 \\
2. & Settlement & 911 \\
3. & Government & 26 \\
4. & Social & 24 \\
5. & Potential conversion & 1,636 \\
\hline & Total & $\mathbf{1 0 , 1 0 6}$ \\
\hline
\end{tabular}

Figure 8 shows the types of encroachment in Bara district:

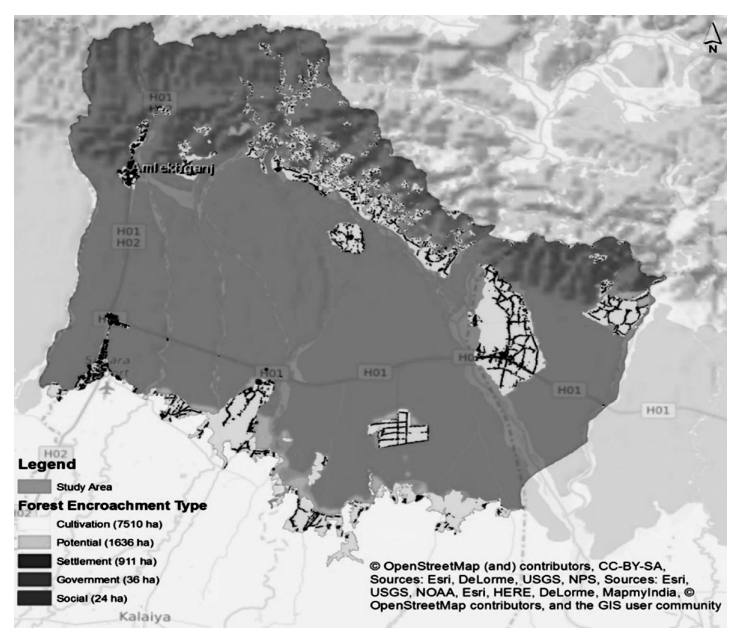

Fig. 8: Type of forest encroachment in Bara district

\section{Conclusion}

The encroachment analysis was based upon visual interpretation techniques. The analysis has been done at the scale of 1:1000 with ground truthing. If the Google maps and high-resolution satellite imageries are available at the time of forest survey, the encroached forest areas can be easily detected by updating the forest cover maps. In this study, an area of 8,540 ha was found to be encroached in the district in the last 50 years (1964-2014). Most of the forest encroachments were found to have been done during the period of 1964-1994 when 6,038 ha forest had been encroached whereas only 2,502 ha forest area was found to have been encroached during the period of 1994-2014.

Besides, the methodology used to assess the encroachment could have been more effective if differential GPS were used. The reference error of the Aerial Photos used during the process of geo-referencing and the low-resolution aerial photographs are some limitations of the study. If this methodological framework is accepted, this pilot project can be applied to detect the encroached forest areas in the other districts of the nation. This analysis will provide a base for detection and management of the encroached forest areas. Furthermore, the definition of encroachment needs to be standardized, which has become a major gap in policy. Forest losses due to forest-fire, landslides, and soil erosion are natural phenomenon, and were not considered under this study. 


\section{Acknowledgements}

We would like to thank the Hariyo Ban Program, WWF Nepal for providing all the resources required to carry out this study. Similarly, we are also thankful to the Department of Forest Research and Survey (DFRS) for providing us some necessary data and technical support.

\section{References}

Acharya, K. P., Dangi, R. B. and Acharya, M. 2011. Understanding the forest degradation in Nepal. Unasylva 62 (238): 31-38.

DFRS. 1999. Forest resources of Nepal (19871998). Publication No. 74. Forest Resource Information System Project. Department of Forest Research and Survey (DFRS), Ministry of Forests and Soil Conservation, Kathmandu, Nepal, 1-33.

DNPWC. 2016. Annual Report 2016. Department of National Parks and Wildlife Reserves (DNPWC), Ministry of Forests and Soil Conservation. Kathmandu, Nepal, 1-16.
DoF. 2016. Community Forestry Bulletin 2016. Department of Forests (DoF), Ministry of Forests and Soil Conservation, Kathmandu, Nepal, 48.

Geist, H. J. and Lambin, E. F. 2001. What Drives Tropical Deforestation? A Meta-Analysis of Proximate and Underlying Causes of Deforestation Based on Sub-national Case Study Evidence. Louvain-la-Neuve (Belgium): LUCC International Project Office, LUCC Report Series No. 4.

Nagendra, H. 2001. Using remote sensing to assess biodiversity. International Journal of Remote Sensing 22: 2377-2400.

Tole, L. 1998. Source of deforestation in tropical developing countries. Environmental Management 22: 19-23.

WWF. 2014. Assessment of Impacts of Migration on Biodiversity, Forest and Local Communities. Hariyo Ban Program, World Wildlife Fund (WWF), Kathmandu, Nepal, 62. 